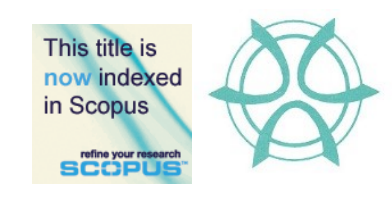

PLANNING MALAYSIA:

Journal of the Malaysian Institute of Planners

VOLUME 19 ISSUE 3 (2021), Page 387 - 399

\section{THE GAP BETWEEN HOUSING AFFORDABILITY AND AFFORDABLE HOUSE: A CHALLENGE FOR POLICY MAKERS}

\author{
Najihah Azmi', Ahmad Ariffian Bujang ${ }^{2}$ \\ Faculty of Built Environment and Surveying, \\ UNIVERSITI TEKNOLOGI MALAYSIA
}

\begin{abstract}
Much of the literature defines housing affordability as the relationship between household income and housing expenditure (housing costs). Affordable housing refers to the affordability of the household to own or rent the housing. Housing becomes unaffordable if the housing costs exceed the income of the household. Thus, the objective of this paper is to define the difference between housing affordability and an affordable house and to identify the factors influencing the gap between housing affordability and an affordable house. To achieve the objectives of this paper, 28 variables or factors have been identified. These variables or factors are then analysed by using the descriptive method of analysis. After analysing 28 identified variables or factors, the findings show that a high house price, a high monthly repayment, the type of property ownership and the land area either extremely or moderately influenced the gap between housing affordability and an affordable house.
\end{abstract}

Keyword: Housing Affordability, Affordable House, Mortgage, Housing Policy

2 Associate Professor at Universiti Teknologi Malaysia. Email: ahmadariffian@utm.my 
Najihah Azmi, Ahmad Ariffian Bujang

The Gap Between Housing Affordability and Affordable House: A Challenge for Policy Makers

\section{INTRODUCTION}

Public concern over housing affordability arises from housing being the single largest expenditure item in a household budget and the increases in housing and rental prices (Quigley and Raphael, 2004). This situation creates problems for the medium- and low-income groups. Devenport (2003) found that low and medium income families found it increasingly difficult to access adequate affordable housing. The existing housing policy restricts the maximum income level for affordable housing without explaining the exact affordable amount. Thus, this condition will create a gap between affordable housing and housing affordability. According to Yates (2008), the rising issues of housing affordability are due to the increment of house prices compared to household income. In addition, the current trend of housing development focuses more on high-cost housing than affordable housing. The property market report in the first half of year 2019 (NAPIC, 2019) revealed that only $20 \%$ of the launched residential units in Johor are priced at RM300,000 and below in the first quarter of year 2019. The new stocks of housing supply in Johor are unaffordable for the majority of the community with a median income of RM5,197. The mismatch between demand and supply has led to a large number of unsold properties.

There is evidence of discrimination in the affordable housing schemes launched by the government such as PR1MA, which has a price range of RM $400,000.00$ and below. The price tag is beyond the affordability of the population. As a result, there is the excess of unsold properties including the ones under the affordable housing scheme. According to the property market report in the first half of 2019 (NAPIC, 2019), there were 6,195 units of unsold properties worth RM4.46 billion in Johor. Hence, policymakers should be aware of the new paradigm for the concept of affordable housing and housing affordability. The objectives of this study are to analyse the gap between affordable housing and housing affordability and identify factors that increase the gap between affordable housing and housing affordability.

\section{HOUSING AFFORDABILITY VS AFFORDABLE HOUSING}

Housing affordability is linked to the relationship between household income and housing costs (Kutty, 2010; Hancock, 1993; Crowley, 2003). Ndubueze (2007) defined housing affordability as the ability to own a house. There are various interpretations of the relationship between housing costs and income. For example, the United States targeted $30 \%$ of the income (Linneman \& Megbolugbe, 1992) while Canada set 20 to $25 \%$ of the income for housing expenditure (Hulchanski, 1995). Gan and Hill (2009) and Bujang, Zarin, and Jumaidi (2010) proposed the concept of housing affordability according to three matters: 
PLANNING MALAYSIA

Journal of the Malaysia Institute of Planners (2021)

\section{i) Purchasing Affordability}

Purchasing ability refers to the ability to obtain sufficient loan for home purchase (Gan \& Hill, 2009; Bujang, Abu Zarin \& Jumaidi, 2010). Bourassa (1996) mentions that the main restrictions on homeownership are obtaining housing loan, the ability to pay housing deposits, and the housing costs in homeownership. Bourassa (1996) also highlights the importance of financial stability in obtaining a mortgage loan. This statement is similar to Trimbath and Montoya (2002) who highlight the three dimensions for housing affordability, namely house price, household income, and mortgage or end financing interest rates. In addition, the purchasing ability depends on house prices and interest rates that affect the overall cost of homeownership financing (Yates, 2008; Osman et al, 2016).

\section{i) Mortgage repayment Affordability}

Mortgage repayment ability refers to the burden experienced by the household members in repaying the mortgage loan. The household members have the repayment ability if they could afford to repay the mortgage loan after deducting other non-housing related costs (Yang \& Wang, 2011). It is the act of setting aside fixed payments for housing costs on a monthly or yearly basis without facing other costs of living pressures. Besides that, they should also consider other housing costs in ensuring homeownership security. In Malaysia, property owners have to deal with monthly and annual costs such as land tax, assessment tax, and management fees as stated in the National Land Code 1965, Local Government Act 1976 and Strata Management Act 2013.

\section{ii) Income affordability}

Income affordability refers to the purchasing power of the household. Besides that, income affordability refers to the ratio of house price to the annual income median which affects the type or price of the house that can be owned or rented by owners. Income affordability can also influence the ability to buy and repay mortgage loans. When the ratio of house price to household income is high, the household's ability to own a house becomes low.

There is no specific definition of affordable housing. Gabriel, Jacob, Arthurson, Burke, and Yates (2005) defined affordable housing as the housing project provided by the government or private sector to meet the benchmark level of affordability (house price or income). In Australia, Urban Research Centre (2008) defined affordable housing as a suitable home for low and mediumincome households due to the low and medium house prices that allow them to afford other basic living expenses without any pressure. Stone (2006) affirms that affordable housing is not only the provision of affordable housing but also a scheme or financial assistance for low and medium-income groups that are experiencing difficulties in the housing market. Some houses are affordable to some people despite their exorbitant price (Stone, 2006). On the other hand, some 
Najihah Azmi, Ahmad Ariffian Bujang

The Gap Between Housing Affordability and Affordable House: A Challenge for Policy Makers

people cannot afford them unless the houses are free. Hence, affordable housing project should be affordable to the community.

\section{HOUSEHOLD AFFORDABILITY BASED ON THE PRESENT}

VALUE OF AN ANNUITY (PV $\left.{ }_{A}\right)$

Baum and Mackmin (1989) explain the formula as follow: when $\$ 1$ is invested today at the interest rate, $i$, the total return on investment during the first year is $(1+i)$. When the total return on investment is $A$ at the end of $n$ years, the formula is as follows:

$$
\mathrm{A}=(1+i)^{\mathrm{n}}[1]
$$

If $x$ is invested today at an interest rate $i$ for $n$ years, and assuming the investment amount is $\$ 1$. By putting 1 and $x$ into equation 1 :

$$
\begin{aligned}
& 1=x(1+i)^{n} \\
& x=\frac{1}{(1+i)^{\mathrm{n}}}
\end{aligned}
$$

$x$ is the present value of $\$ 1$. The present value of the first year of income instalment is $\frac{1}{(1+i)}$. For the payment for $n$ year, the present value for $n$ year is as follows:

$$
\frac{1}{1+i}+\frac{1}{(1+i)^{2}}+\frac{1}{(1+i)^{3}}+\ldots \ldots . . \frac{1}{(1+i)^{n-1}}+\frac{1}{(1+i)^{n}}[3]
$$

Thus, geometric progression is performed and the present value of annuity, $\mathrm{PV}_{\mathrm{A}}$, is as follows:

$$
P V_{A}=\frac{1-\frac{1}{(1+i)^{n}}}{i}[4]
$$

The present value of annuity is also known as year purchase single rate by the valuation surveyors (Baum et al., 2011). The assumption of this formula is the fixed interest rate throughout the financing period.

\section{MEASURING HOUSE PRICE BASED ON HOUSING AFFORDABILITY RATES}

The standard used to measure housing affordability is the allocation of $30 \%$ from the household income for housing costs Hulchanski, 1995; Linneman \& Megbolugbe, 1992). Bujang (2006) suggested measuring house prices based on 
the housing affordability levels of homebuyers using the mortgage loan formula (Goebel \& Miller, 1981) as follows:

$$
\begin{aligned}
& \$ P V=\$ P V_{A} \text { (annuity) }[5] \\
& \text { Mortgage loan value }=\$ P V_{A} \text { (annuity) [6] }
\end{aligned}
$$

Figure 1 shows the annuity in the mortgage loan equation, which is $30 \%$ from the household income for housing costs. Figure 1 describes the estimation of home price or housing loan (including interest rates for financing period, $n$ ) of the maximum mortgage loan that can be achieved by households. It is based on the ratio standard used in housing affordability study, which is $30 \%$ from the household income. Hence, equation 4 and $30 \%$ of the household annual income are included in equation 6 . $\mathrm{Hg}$ is the maximum house price that can be bought or owned.

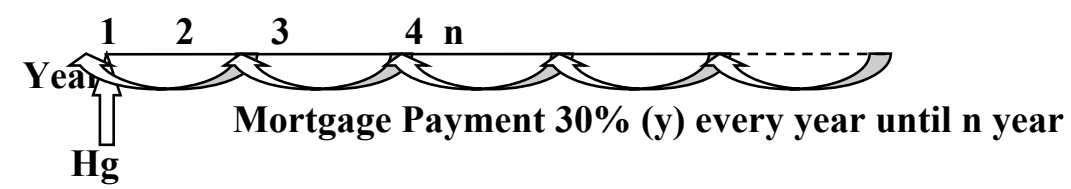

Figure 1: The estimation of the present price of affordable housing is based on household income using the year's purchase single rate. $y=$ household income at an interest rate, $\mathrm{Hg}$ $=$ mortgage loan, and $n=$ financing period

$$
H g=30 \%(y) \times \frac{1-\frac{1}{(1+i)^{n}}}{i}(7)
$$

Where $y=$ household income

$\mathrm{Hg}=$ household's maximum housing loans

$n=$ housing loan financing period

$i=$ end financing interest rate

The above formula shows the relationship between household income $(y)$ and interest rate $(i)$ throughout the financing period $(n)$ to obtain the housing prices based on housing affordability (income affordability). The above formula also explains how much money is allocated for housing fixed cost from the income, either yearly or monthly, after purchasing the affordable house. The common allocated percentage is $30 \%$ of household income that considers the interest rate for end financing over a specified period. This formula shows that affordable home prices can be calculated using household income, interest rates, and financing period. The $30 \%$ of household income should considered other housing costs such as maintenance, insurance, and other aspects.

\section{AFFORDABLE HOUSE PRICE}

Goebel and Miller (1981) presented the following formula: 
Najihah Azmi, Ahmad Ariffian Bujang

The Gap Between Housing Affordability and Affordable House: A Challenge for Policy Makers

Mortgage loan $=\$ P V_{A}$ (annuity)

Where, annuity is the housing loan annual payment.

Mortgage payment $=$ Mortgage loan $(1 / \mathrm{PV})[8]$

Equation 4 is included in equation 8 ,

Mortgage payment = Mortgage loan $\left(\frac{1}{\frac{1-\frac{1}{(1+i)^{n}}}{i}}\right)^{[9]}$

Mortgage payment $=$ Mortgage loan $\left(\frac{i}{1-(1+i)^{-n}}\right)_{[10]}$

Where $=$ housing mortgage period

$i=$ end financing interest rate

Figure 2 shows the movement of mortgage loans that should be paid by households during the house financing period. Affordable housing concept is based on the price offered that calculates the amount of monthly or annual instalment payment based on the interest rate and specified financing period.

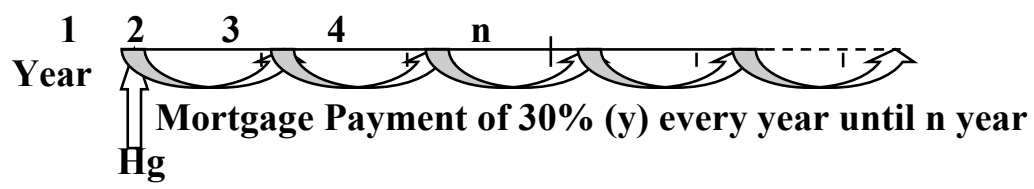

Figure 2: The movement of the mortgage loan, $H g$ = the sum of affordable house price/mortgage loan, and $n=$ financing period

\section{FACTORS THAT INFLUENCED THE GAP BETWEEN HOUSING AFFORDABILITY AND AFFORDABLE HOUSE}

Generally, house prices are influenced by demand and supply, which are important in the residential property market. The relationship between demand and supply can determine a balance point in the market prices. Bujang (2006), Rowan-Robinson \& Llyod (1988) and Harvey \& Jowsey (2004) affirm that house prices are influenced by demand and supply, as well as household ability and desire. Household ability and desire are closely related to the aspects of socioeconomic, environment, type and accommodation besides being subjected to market speculation, including the existing stocks. 
PLANNING MALAYSIA

Journal of the Malaysia Institute of Planners (2021)

Economists debated that the rise in commodity prices is due to the macroeconomic and socio-demographic of the population. Positive economic and socio-demographic growth of the population, such as gross domestic product (GDP) growth (Clark \& Coggin, 2011; Dreger \& Zhang, 2013; Ren, 2012), household income growth (Clark \& Coggin, 2011; Garcia \& Hernandez, 2008), population (Ren \& Xion, 2012), household size (Garcia \& Hernandez, 2008), and interest rates (Dreger \& Zhang, 2013; Himmelberg, Mayer \& Sinai, 2005; Mayer \& Quigley, 2003) can influence changes in the commodity demand. In addition, the government policy on housing, either fiscal or non-fiscal policy, can influence the demand in the housing market. When the fundamental economic factors cannot justify price growth, the market bubble will occur as investors are confident in obtaining profit returns. The bubble in the market happens if there is an increase in commodity price when investors are engaged in speculative activities and manipulative prices for profit. This situation will increase the demands in the market (Mill, 1885). ). Stiglits (1990) (cited by Himmelberg, Mayer \& Sinai, 2005) define a bubble as, "If the reason that the price is high today is only because investors believe that the selling price is high tomorrow -when 'fundamental' factors do not seem to justify such a price -- then a bubble exists. At least in the short run, the high price of the asset is merited, because it yields a return (capital gain plus dividend) equal to that on alternative assets"

The market bubble occurs when there is a financial liberalisation by the central bank, which focuses on the credit growth that can increase housing demand and asset prices (Malpezzi \& Wacther, 2005). This situation happens because the end financing for buying or investing the residential property sector is readily available by the speculative investors. A market bubble occurs when there is a rapid rise in the demand in the market at a given time (Melpezzi \& Wachter, 2005; Glaeser, Gyourko \& Saiz, 2008; Huang \& Tang, 2012; Capozza, Hendreshott \& Mack, 2004). At the same time, the supply rate remains constant with the inelastic demand. This situation has led to a rapid rise in the commodity market price. In Johor, the housing market experienced a bubble from year 2012 to 2014 before the downturn in year 2015 due to the introduction of developer interest bearing scheme (DIBS) by Bank Negara Malaysia in resolving the excess amount of unsold properties since the global economic decline in year 2009. The DIBS scheme is similar to an adjustable mortgage, which is one of the major causes of the subprime mortgage crisis. The scheme encourages the speculative activity as the end financing is readily available to homebuyers. The scheme also causes a 30 per cent increase in the DIBS house prices. Homebuyers are generally unaware of the additional costs due to the lack of transparency concerning important information. The scheme has resulted in a median increase in house price although there has been a decline in the excess of real estate as a result of the global economic downturn in year 2009. According to Khazanah Research Institute (2019), the value of compound annual growth rate (CAGR) from year 
Najihah Azmi, Ahmad Ariffian Bujang

The Gap Between Housing Affordability and Affordable House: A Challenge for Policy Makers

2012 to 2014 for median house prices was 23.5 per cent compared to the 11.17 per cent increase in household income for the same period. The system was discontinued in year 2014 to control the high house prices in the market (Bank Negara Malaysia, 2017).

The supply reaction increases due to the excess supply of unsold or overhang market (Pirounaski, 2013). Gross (2007) stated that the bubble in the real estate market causes the excess of unsold properties due to the rise of excessive properties during the market bubble. Barras (2007) mentioned that the demand for new development in the real estate sector is decreasing after the bubble bursts that produce excessive properties. The residential property condition is undervalued due to the high supply and surplus as there is a lack of demand for certain types and prices of properties. The lack of demand is due to high costs, undesirable location and accessibility, less attractive design, less attractive neighbourhoods, and failure to attract the target group. The difficulty of obtaining end financing loan has also affected the number of unsold residential properties.

Beside that, location and microeconomic factors in housing market should be considered because it also gives impact to houses price. Harvey and Jowsey (2004) provided the three main determinants of residential location valuation, namely accessibility, environmental features, and rentals. Location is the most important factor in the housing market. The features of an attractive location are as follows: (1) the physical features of the neighbourhood; (2) neighbourhood social characteristics; (3) public services and facilities in the neighbourhood; (4) environmental quality in the neighbourhood; and (5) accessibility. Hassan et al (2018) \& Hassan et al (2021) found that location factor give impact on housing affordability. The micro-economic factor in the housing market can influence house prices. Previous studies revealed that housing characteristics, such as land area, lot location, and lot size have a big impact on house prices (Nashan, 2010; DiPasquale \& Wheaton, 1995; Yang \& Shen, 2008; Tiwari \& Parikh, 1998).

\section{METHODOLOGY}

The results from previous studies and questionnaire survey were gathered to achieve the research objectives. This study used random sampling method. Besides that, the researcher used the formula by Israel (1992) to determine the population size and the number of respondents in this study. The chosen confidence level is 95 per cent with the assumption of 5 per cent probability in which the actual percentage is not within the selected confidence interval (Israel, 1992). The researcher referred to the number of households in Johor Bahru and determined that the number of respondents for this study should be at least 400 . This study used the calculation of sample size as follows: 
PLANNING MALAYSIA

Journal of the Malaysia Institute of Planners (2021)

$$
n=\frac{N}{1+N(e)^{2}}
$$

Where, $n$ : the number of questionnaires, $\mathrm{N}$ : total population, e: confidence level, thus;

$=\frac{331095}{828.7375}$

$$
\text { Number of questionnaires }=\frac{331095}{1+331095(0.05)^{2}},
$$

$$
=399.5 \cong 400 \text { respondents }
$$

The questionnaire was divided into three sections, namely the sociodemographic of the respondents, house ownership status, and the factors affecting the incompatibility of housing affordability and affordable housing. This study used the 5-point Likert scale (not influential, slightly influential, moderately influential, influential, and highly influential) to test the variables. The nominal data were analysed using frequency and percentage distribution, whereas the ordinal data were analysed using relative importance index (RII). The RII formula by Ensansi et al. (2012) is as follows:

$$
R I I=\frac{\sum W}{A N}=\frac{1 n_{1}+2 n_{2}+3 n_{3}+4 n_{4}+5 n_{5}}{5 N}
$$

Where: $w$ : weighting given to each factor by the respondents

$A$ : highest scale value

$N$ : total number of respondents

The RII range is from 0 to 1 .

\section{RESULTS AND FINDINGS}

In general, the majority of the respondents are Malay (278 or $77 \%$ ), the working group is in the age range between 21 to 60 years old (345 or 96\%), and married $(203,56 \%)$. Besides, the majority of the respondents earned RM5,000.00 and below ( 267 or $74 \%$ ). The housing ownership rate among the respondents was moderate. About 178 people or $49.4 \%$ of the respondents owned a house while the remaining respondents rented houses or stayed with their family.

Table 4 shows the incompatibility rankings of housing affordability and affordable housing. RII analysis shows that housing affordability factor has the highest ranking for the following variables: high house prices and high monthly commitment of housing costs experienced by households. The least dominant factor is close to the recreational area. It can be concluded that house price is an important indicator compared to household income. 
Najihah Azmi, Ahmad Ariffian Bujang

The Gap Between Housing Affordability and Affordable House: A Challenge for Policy Makers

Table 4: RII analysis

\begin{tabular}{|l|r|}
\hline Variables & $\begin{array}{l}\text { RII } \\
\text { Value }\end{array}$ \\
\hline KP1 High house prices & 0.88 \\
\hline $\begin{array}{l}\text { KP2 High monthly payment (more than 30\% of the monthly household } \\
\text { income) }\end{array}$ & 0.80 \\
\hline FR5 Types of property ownership (e.g.: freehold or leasehold) & 0.80 \\
\hline FR4 Land area & 0.79 \\
\hline L5 Have a good public transport system & 0.78 \\
\hline L1 Close to workplace & 0.78 \\
\hline CKP2 Security aspect influences house price (e.g.: gated community) & 0.78 \\
\hline Variables & $\begin{array}{l}\text { RII } \\
\text { Value }\end{array}$ \\
\hline CKP4 Guarantee a good and conducive environment in the housing package & 0.78 \\
\hline $\begin{array}{l}\text { L4 Close to community facilities (e.g.: post office, places of worship, } \\
\text { hospital) }\end{array}$ & 0.77 \\
\hline $\begin{array}{l}\text { FR3 The quality of building and finishing materials (e.g.: using expensive } \\
\text { tiles, etc.) }\end{array}$ & 0.77 \\
\hline L2 Close to the city centre & 0.76 \\
\hline FP3 Speculation in the housing market & 0.76 \\
\hline $\begin{array}{l}\text { CKP1 Additional provision of community and public facilities which lead to } \\
\text { increasing the house prices (e.g.: sports club, swimming pool) }\end{array}$ & 0.76 \\
\hline FR1 Types of house in the market & 0.75 \\
\hline L3 Close to commercial/business facilities & 0.75 \\
\hline FP1 Basic factors in the market (e.g.: interest rate, population) & 0.74 \\
\hline KP4 Not receiving financial facilities & 0.74 \\
\hline FR2 Luxury home design (e.g.: in-house landscaping, bathtub, etc.) & 0.74 \\
\hline $\begin{array}{l}\text { CKP3 Luxury lifestyle is offered and sold in housing packages by developers } \\
\text { (e.g.: sports club, golf course) }\end{array}$ & 0.74 \\
\hline KP5 Side costs in the home buying process (e.g.: legal fees, stamp duty) & 0.73 \\
\hline FP2 Government housing development plans and policies & 0.72 \\
\hline $\begin{array}{l}\text { KP3 Unable to prepare 10\% of deposit payment charged during home } \\
\text { purchase }\end{array}$ & 0.71 \\
\hline L6 Close to the recreational area & 0.70 \\
\hline
\end{tabular}

\section{DISCUSSION AND CONCLUSION}

Housing affordability is an important indicator of the economic well-being of a country (Berry, 2006). The existing housing policy restricts the maximum income level for affordable housing without explaining the exact affordable amount. This finding resulted in a mismatch between affordable housing and housing affordability, particularly its conceptual foundations, and the supply and demand of affordable housing. In addition, to formulate policies to solve the problem of housing affordability, the identification of the factors that cause the occurrence of a mismatch or gap between affordable housing and housing affordability is 
important; this will also bridge the mismatch that occurs. This formulation can indirectly control house prices and reduce the excess property.

Housing affordability has emerged as the key challenge confronting housing policy makers. Therefore, addressing affordability problems is currently a priority for governments in many countries, and a broad variety of strategies are being enacted to improve the efficiency of housing markets, to increase supplies of affordable housing, to respond to housing-related financial pressures on individual households and to promote housing finance options for those households being excluded from the housing market. Changes to the social housing system are required to ensure the viability of this existing source of lowcost housing and to better integrate existing service providers and assets into an expanding sector of affordable housing. In particular, reform should be oriented towards overcoming the current residualisation of this sector and towards increasing housing and other options and, where needed, the mobility of those lower-income households who rely most on social housing. In conclusion, a joint, strongly coordinated national framework is important to address Malaysia's housing affordability catastrophe and to mitigate the broader risks that the systemic decline in housing affordability poses to future generations. Addressing this crisis requires leadership from all sectors of government and a long-term commitment to a whole-government approach that uses housing and non-housing public policy levers.

\section{REFERENCES}

Bank Negara Malaysia. (2017). Debunking the Myth: Property Measures Have Led To Higher Loan Rejection Rate. Kuala Lumpur: Bank Negara Malaysia.

Baum, A., \& Mackmin, D. (1989). Valuation Mathematic. In A. Baum, \& D. Mackmin, The Income Approach to Property Valuation (pp. 3-52). London: Routledge \& Kegan Paul.

Baum, A., Mackmin, D., \& Nunnington, N. (2011). The Income Approach to Property Valuation. New York, USA: Routledge.

Bourassa, S. C. (1996). Measuring the Affordability of Home-ownership. Urban Studies, 1867-877.

Bujang, A. A. (2006). Pemilikan Harta Tanah Kediaman: Satu Kajian Penilaian Ke Atas Peraturan Kuota Lot Bumiputera Di Daerah Johor Bharu. Kuala Lumpur: Universiti Malaya.

Bujang, A. A., Zarin, H. A., \& Jumadi, N. (2010). The Relationship Between Demographic Factor and Housing Affordability. Malaysian Journal of Real Estate, 49-58.

Capozza, D. R., Hendershott, P. H., \& Mack, C. (2004). An Anatomy of Price Dynamics in Illiquid Markets: Analysis and Evidence from Local Housing Markets. Real Estate Economics, 1-32..

Clark, S. P., \& Coggin, T. D. (2011). Was there a U.S. house price bubble? An econometric analysis using national and regional panel data. The Quarterly Review of Economics and Finance, 189-200. 
Najihah Azmi, Ahmad Ariffian Bujang

The Gap Between Housing Affordability and Affordable House: A Challenge for Policy Makers

Crowley, S. (2003). The Affordable Housing Crisis: Residential Mobility of Poor Families and School Mobility of Poor Children. The Journal of Negro Education, 22-38.

Davenport, J. L. (2003). The Effect of Supply and Demand Factors on the Affordability of Rental Housing. Bloomington, USA: Illinois Wesleyan University.

DiPasquale, D., \& Wheaton, W. C. (1996). Chapter 2 The Operation of the Property Market: A Macro and Micro Approach. In D. DiPasquale, \& W. C. Wheaton, Urban Economics and Real Estate Market (pp. 22-32). Englewood Cliffs, N. J.: Prentice Hall.

Dreger, C., \& Zhang, Y. (2013). Is there a Bubble in the Chinese Housing Market? . Urban Policy and Research, 27-39.

Enshassi, A., Arain, F., \& Tayeh, B. (2012). Major causes of problems between contractors and subcontractors in the Gaza Strip. Journal of Financial Management of Property and Construction, 92-112.

Gabriel, M., Jacobs, K., Arthurson, K., Burke, T., \& Yates, J. (2005). Conceptualising and measuring the housing affordability problem. Sydney: Australian Housing and Urban Research Institute (AHURI).

Gan, Q., \& Hill, R. J. (2009). Measuring housing affordability: Looking beyond the median . Journal of Housing Economics, 115-125.

García, J. A., \& Hernández, J. E. (2008). Housing demand in Spain according to dwelling type: Microeconometric evidence . Regional Science and Urban Economics , $363-$ 377.

Glaeser, E. L., Gyourko, J., \& Saiz, A. (2008). Housing supply and housing bubbles . Journal of Urban Economics, 198-217.

Goebel, P. R., \& Miller, N. G. (1981). Handbook of Mortgage Mathematics and Financial Tables . Englewood Cliffs, NJ: Prentice-Hall.

Hancock, K. E. (1993). 'Can Pay ? Won't Pay? or Economic Principle of Affordability. Urban Studies, 127-145.

Harvey, J., \& Jowsey, E. (2004). Urban Land Economics. Basingstoke: Palgrave MacMillan.

Hassan, M. A., Hamdan, H., Abdullah, J., \& Abdullah, Y. A. (2018). Housing and Transport Expenditure: An Assessment of Location Housing Affordability. . Planning Malaysia: Journal of the Malaysian Institute of Planners, 99-108.

Hassan, M. A., Abdullah, Y. A., Omar, D., \& Danial, M. H. (2021). Location Housing Affordability Index: Analysing The Relationships. Planning Malaysia: Journal of the Malaysian Institute of Planners, 218-228., 41-52.

Himmelberg, C., Mayer, C., \& Sinai, T. (n.d.). Assessing High House Price: Bubble, Fundamental and Misperceptions. NBER Working Paper (pp. 1-21). 2005.

Huang, H., \& Tang, Y. (2012). Residential land use regulation and the US housing price cycle between 2000 and 2009. Journal of Urban Economics, 93-99.

Hulchanski, J. D. (1995). The concept of housing affordability: Six contemporary uses of the housing expenditure-to-income ratio. Housing Studies, 471-491.

Khazanah Research Institute. (2019). Rethinking Housing: Between State, Market and Society. Kuala Lumpur: Khazanah Research Institute.

Kutty, N. K. (2010). A new measure of housing affordability: Estimates and analytical results. Housing Policy Debate, 113-142. 
Israel, G. D. (1992). Determining Sample Size. Florida: University of Florida.

Linneman, P., \& Megbolugbe, I. (1992). Housing Affordability: Myth or Reality? Urban Studies, 369-392.

Malpezzi, S., \& Wachter, S. M. (2005). The Role of Speculation in Real Estate Cycles . Journal of Real Estate Literature, 141-164.

Mayer, C., \& Quigley, J. M. (2003). [Is There a Bubble in the Housing Market?]. Comments and Discussion . Brookings Papers on Economic Activity, 343-362

Mill, J. S. (1885). The Project Gutenberg EBook of Principles Of Political Economy. New York: D. Appleton And Company, .

Nashan, A. M. (2010). Penentuan Harga Rumah Berdasarkan Faktor-Faktor Mikro. Johor Bharu: Universiti Teknologi Malaysia.

Ndubueze, O. (2007). Measuring Housing Affordability: A Composite Approach. ENHR 2007 International Conference 'Sustainable Urban Areas', (pp. 1-43). Rotterdam.

Pirounakis, N. G. (2013). Real Estate Economics. London \& New York: Routledge.

National Property Information Centre (NAPIC). (2005-2019). Property Market Report 2005-2019. Kuala Lumpur: Pusat Maklumat Harta Tanah Negara (NAPIC).

Osman, M. M., Zainudin, F. E., Rabe, N. S., Hitam, M., \& Ponrahono, Z. (2020). Challenges and Ownership Issues Facing By Low (B40) and Medium Income Group (M40) In Selangor. Planning Malaysia: Journal of the Malaysian Institute of Planners, 218-228.

Quigley, J. M., \& Raphael, S. (2004). Is Housing Unaffordable? Why Isn't It More Affordable. Journal of Economic Perspectives, 191-214.

Ren, Y., Xiong, C., \& Yuan, Y. (2012). House price bubbles in China . China Economic Review, 786-800..

Rowan-Robinson, J., \& Lloyd, M. (1988). The infrastructure lottery and the land development process. Land Development Studies, 17-30.

Stone, M. E. (2006). What Is Housing Affordability? The Case for the Residual Income Approach . Housing Policy Debate, 151-184.

Tiwari, P., \& Parikh, J. (1998). Affordability, Housing Demand and Housing Policy in Urban India . Urban Studies, 2111-2129.

Trimbath, S., \& Montoya, J. (2002, Disember 13). Housing Affordability in Three Dimensions: Price, Income and Interest Rates. Retrieved from Milken Institute Policy Brief No. 31: https://ssrn.com/abstract $=349681$ or http://dx.doi.org/10.2139/ssrn.349681.

Urban Research Centre. (2008). Housing Affordability Literature Review and Affordable Housing Program Audit. Sydney: University of Western Sydney.

Yang, Z., \& Shen, Y. (2008). The affordability of owner occupied housing in Beijing . $J$ Hous and the Built Environ, 317-335.

Yang, Z., \& Wang, S. (2011). The impact of privatization of public housing on housing affordability in Beijing: An assessment using household survey data . Local Economy, 384-400.

Yates, J. (2008). Australia's Housing Affordability Crisis . The Australian Economic Review, 200-214

Received: $12^{\text {th }}$ July 2021 . Accepted: $17^{\text {th }}$ Sept 2021 